\title{
LEGAL EDUCATION AS A METHOD FOR MITIGATING DEVIANT BEHAVIOR OF MINORS
}

Nataliia Martynova, $\mathrm{PhD}$ in Education

Nataliia Borovkova, PhD in Philology

Nosov Magnitogorsk State Technical University

Magnitogorsk, Russia

\begin{abstract}
This article studies legal education as a method for mitigating deviant behavior of minors. It analyzes importance of legal culture of teens that can be fostered by forms and methods of educational environment, improves activity of the young, regulated individual behavior based on moral motivation of the personality. Need and expediency of sense of justice which acquaints minors with knowledge of the state and the right, legality, the rights and personal freedoms, development at teenagers of steady orientation to law-abiding behavior is defined.
\end{abstract}

Keywords: legal education, educational environment, deviant behavior, moral motivation.

Resumo: Este artigo estuda a educação jurídica como um método para mitigar o comportamento desviante dos menores (sic). Analisa a importância da cultura jurídica dos adolescentes que pode ser promovida por formas e métodos de ambiente educacional, melhora a atividade dos jovens, regula o comportamento individual baseado na motivação moral da personalidade. É definida a necessidade e a conveniência do senso de justiça que familiarizam os menores ( $\mathrm{sic}$ ) com o conhecimento do Estado e o direito, a legalidade, os direitos e as liberdades pessoais, o desenvolvimento nos adolescentes de uma orientação constante ao comportamento definido pela lei.

Palavras-chave: educação jurídica, ambiente educacional, comportamento desviante, motivação moral.

The new reasons for upgrading the legal environment, under modern conditions, are created by transparency, democratization of public structures and necessity of establishing a rule-of-law state. At the same time, insufficient development of morality of some young people, legal nihilism, insufficient activity of law-enforcement bodies and some other problems require rethinking of some provisions of legal culture. Under modern conditions, each citizen must be able to apply laws and regulations. It is possible only if the country's population is legally literate.

Development and moral improvement of the public is an integral part of legal education and improvement of legal culture of citizens. This phenomenon is due to legal governance of individual behavior being based on moral motivation of a personality in relation to necessity and practicability of such behavior. In this connection and in Criar Educação, Criciúma, v. 7, no2, julho/novembro 2017.- PPGE - UNESC 


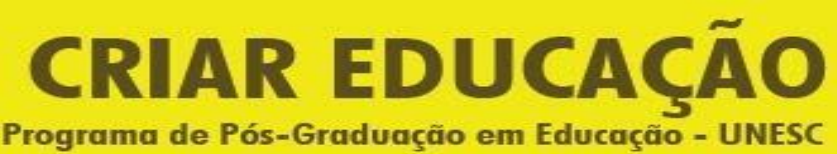

Revista do Programa de Pós-Graduação em Educação - UNESC
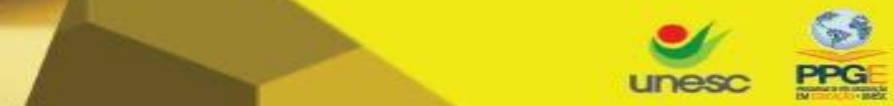

ediunesc

general educational strategy, a public demands for an orientation towards human nobility as well as social responsibility as embodied in legal responsibilities of a citizen is growing more prominent and distinct.

At all stages of state building, special attention has always been paid and is still being paid to the task of fostering, in citizens, of active demand for compliance with moral and legal rules and regulations of the modern society, high civic discipline and organization. Complicating nature of educational activities due to consequences of scientific progress has immeasurably increased requirements to moral and psychological, vocational and legal educational preparedness of all classes of citizens, especially minors.

Legal culture is a phenomenon objective in any respects that is formed under influence of numerous combined factors such as social and economic, political, ethnical and psychological and cultural and historical ones. Still, legal consciousness as a basis of legal culture, requires regular rational fostering, incentivizing and positive social development. The system of actions aimed at integration of political and legal concepts, rules and principles that are values of both national and global legal culture into the people's consciousness is referred to as the legal education.

Legal education is targeted actions of the state, public entities and individual citizens aimed at transfer of legal experience; systemic influence on human consciousness and behavior for the purposes of fostering certain positive concepts, value-oriented opinions and paradigms that ensure compliance, performance and exercise of legal rules. The contents of legal education is providing people with knowledge of the state and law, lawfulness, individual rights and liberties and stably targeting citizens at law-abiding behavior.

Legal education is a complex and multi-faceted system of actions the particular role wherein belongs to the educational system. It is in the teenage age when human personal paradigms are formed one must create bases for fostering law-respecting citizens.

The process of assistance in fostering legal culture in schoolchildren personalities takes on different form and uses different methods, approaches and educational aids. Pedagogical literature refers to the concept of education as the method of organizing the educational process. Organizational forms of the educational 


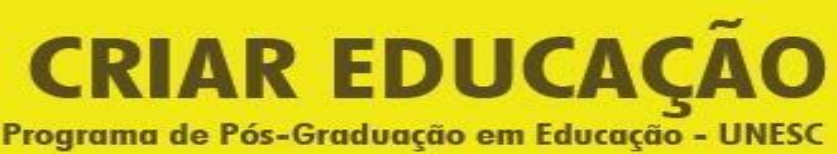

Revista do Programa de Pós-Graduação em Educação - UNESC

process most generally reflect relations being established among the educational process subjects.

Forms of legal education (the same as for the educational methods) are classified depending on the number of students, i.e. inclusion of either the whole class, small groups or individual pupils (front, group and individual operations). It is the most widespread classification. Also proper is the classification of educational organization forms by educational methods:

1) Verbal forms (meetings, combines, lectures, presentations, disputes, etc.);

2) practical forms (sightseeing, Olympics and contests, etc.);

3) visual forms (school museum, legal exhibitions, topical exhibitions, etc.).

The above classifications undoubtedly do not expose the whole wealth of the educational process. The complicated process of moral education includes different organizational forms. Of the above educational forms classification, we consider the first one to ne the most universal.

Educational methods are referred to as methods of interactions between students and teachers as well as organization of their activities. Legal education methods are ways and means of fostering legal consciousness, developing moral feelings and establishing skills and habits of law-abiding behavior. The process of legal culture formation is two-sided. On the one hand, it is organizational targeted influence of teacher, and organized targeted activities of students. Convincing and exercising methods contribute to the process of legal education.

Education is influence on consciousness, senses and will of students to foster positive qualities in them and free them of negative ones. Teacher explains norms and rules of behavior to schoolchildren. Still, convincing goes far beyond mere verbally convincing or discussing. Students learn also from their own experiences, practices, specific deeds and personal examples of the people around them, in particular, teacher and parents, and communication with them. For the purposes of conviction, one uses meeting with representatives of justice authorities, child protection authorities, books, films, TV and radio broadcasts. It all contributes to legal enlightenment of students, provides them with knowledge of rules of conduct, civil rights and obligations, and fosters value orientations. 

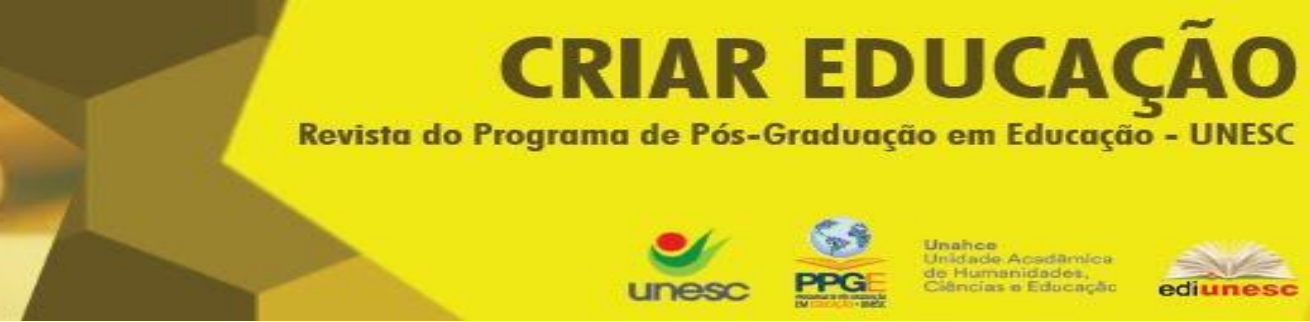

Main forms of a method of belief. Another important aspect of legal education is legal enlightenment. Legal enlightenment, i.e. the process of disseminating legal knowledge, contributes to growth of common legal culture and education. The key objective of legal enlightenment in its capacity of a legal propaganda method is fostering respect of law and lawfulness as value orientations of students.

Homeroom. It is the most widespread form of classroom educational activities. During homerooms, free-form communication of students with their supervising teachers prevails. Homerooms are no usual educational activity. They must be well prepared to be well remembered by schoolchildren by leaving traces in their consciousness and influencing their behavior.

Discussions. Ethical discussions are also prominent in educational activities of supervising teachers. They aim at enriching students with moral concepts and terms associated with positive actions and acts and familiarizing students with rules of conduct. Discussions foster judgmental attitude of students to their behavior and behavior of other people. Efficiency of ethical discussions can be increased by high moral standing and cultural level of supervising teachers, emotions they express when presenting materials, their ability to make students sincere and instill in them trust towards teachers.

On par with regular discussions, irregular ones are held also in connection with discussion of students' actions. Such conversations should be held immediately after an action has been committed. Such discussions can be held either with classes or with individual pupils guilty of ignoble actions. Experience supervising teachers do not rely excessively on collective condemnation of defects in schoolchildren's behavior. In some case, individual discussions with guilty pupils are more efficient. In this case, fostering an atmosphere of benevolence and sincerity is critical.

Another form of moral conviction is the readers' conference. It assists not only in broadening schoolchildren's horizons and fostering their artistic taste but also in instilling in them the forms of legal conduct. Frequently, readers' conferences become discussions or disputes (especially in senior grades). Exercises stand for regularly organized taking of specific actions or performance of practical deeds to create and develop personalities. Exercises functions are not restricted by learning the basics of proper social behavior. Exercises also foster legal culture, establish view and 


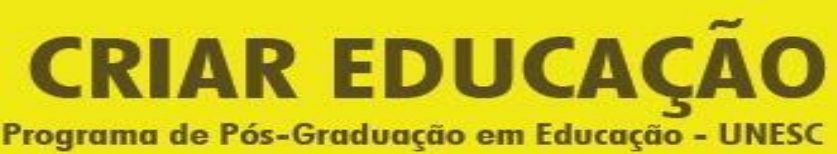

Revista do Programa de Pós-Graduação em Educação - UNESC

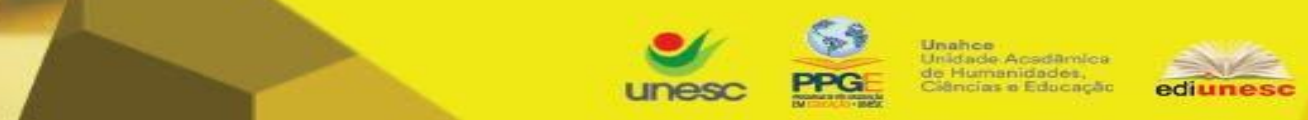

motivations and enrich feelings. Trainings and legal minutes are the most widespread use of the method. Two types of exercises are used in the course of legal education: organizing legal experiences of students by including them into different activities and special exercises for students.

On par with conventional forms of enlightenment activities (the convincing method) aiming at passive perception, interactive forms that incentivize interest and social activity can be used as well as follows: trainings; roleplaying games; discussions (dialogs and collogues); participating in research activities; interactive methods require taking into account nonverbal methods of interaction stimulating internal demand for study of law; discussion methods are very interesting to students and include: free discussions (talk shows, round robins, dialogs); regulated discussions (disputes, discussions, debates).

Debates are a system of formalized discussions on various topics Two teams present their arguments and counterarguments to convince the jury of their correctness and rhetorical experience. Learning debate techniques is an excellent opportunity for the participants thereof to enrich their language and obtain communicative skills. Debates develop logical and critical thinking, skills of organizing one's own thoughts, oral speech skills, empathy and tolerance towards different views, self-confidence, teamwork abilities, and skills of concentrating on the essence of the problem and public speaking skills.

There are many methods for working with discussion problems. They include: "panel discussions" or "expert meetings" that consist in discussing the problem by all group members and subsequent presentation of their positions to the whole class. Four to six persons participate in a discussion including a pre-appointed chairperson. Each participant must make its presentation albeit within the regulations.

Round robins are conversations where all group members (five to six persons) participate equally while other pupils listen and complete the Synthesis table according to the model: opinion - explanation - question. The discussion stops every five minutes and with classmates asking the group question to direct and deepen the discussion. Forums are discussions similar to round robins where the group discuss the problem with its classmates and provides them with a specific resolution on the problem of interest. 


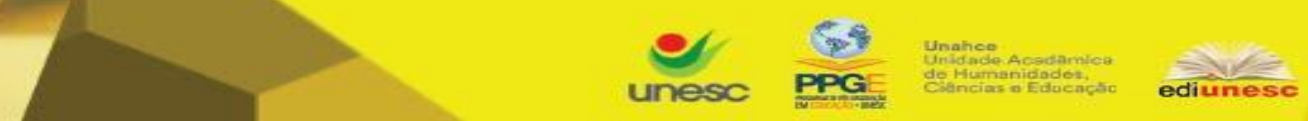

Court hearings are discussions simulating court hearings. Discussion of discussion issues and problems frequently affects personal motivations and provokes emotional reactions, which complicates teachers' actions.

Rules of Discussions:

1. Topics must be critical for the public life of the country and region while, at the same time, being of interest to students given their age and social status distinctions.

2. Prepare materials or references students must read while preparing to the discussion.

3. Select the method of discussion. Think over starter options.

4. Draft a list of questions for guiding the discussion and concentrating attention of the class.

5. Be neutral when presenting the discussion matter.

6. Develop discussion rules jointly with students (e.g., being critical of opinions and not people, lifting hands to ask for permission to speak, not interrupting each other, not talking simultaneously, listening to others' opinions despite disagreeing with them, not going off topic and being concise, etc.).

7. During discussions, make short notes for yourself to facilitate summing up.

8. Actively use nonverbal means such as gestures and mimics to facilitate control of the discussion without interrupting it.

9. Check for indications of sagging of the discussion. Change the assignment if the discussion is sagging.

10. Always leave time for summarizing. The following questions can be used to summarize the discussion: What are the most convincing arguments of both parties? Where can one get additional information on any questions to the list? What can you do if the topic is indeed of interest to you? What alternatives can you propose and to whom?

Games can be considered the only activity aiming not at development of individual skills and competencies, but at developing creativity at large. Roleplaying games should be used in legal education as they incentivize students, assist them in handling social and legal roles while acting in unusual positions (prosecutors, investigators, witnesses, attorneys, judges, etc.). Games are conventional activities requiring regulated behavior according to the rules. Games create models of lawful legal 


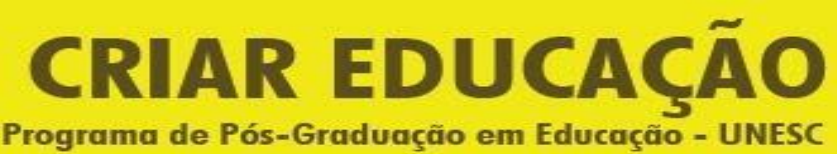

Revista do Programa de Pós-Graduação em Educação - UNESC

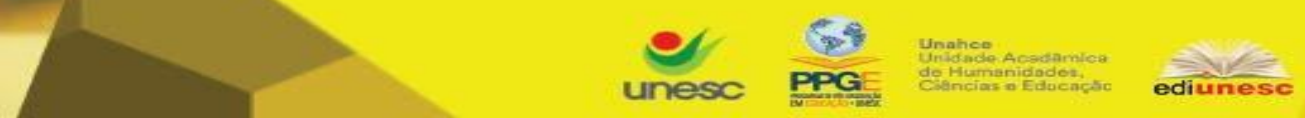

behavior. It is preferable to act out typical situations from lives of specific jobs. Groups search for the best ways out of the situation from their points of view. Still, groups' opinions are not always satisfactory to specific roleplaying game participants or trainers. The results of activities are discussed within a group.

The most efficient forms include remote ones (provided there is reasonable interaction with universities or government justice authorities) that require availability of computers and reference systems (Consultant Plus, Garant, and Codex) to schools and computer user skills. Remote education has the following advantages: high level of independence of students in obtaining legal knowledge and prerequisites for fostering skills of using statutory materials.

To develop moral qualities, one must incentivize or initiate participation of seniors in socially significant deeds (such as volunteering in human rights public associations), school self-governance and youth public organizations, which is an excellent opportunities to try their hands for young leaders.

Project method based contests of social projects prevail among legal education forms incentivizing socially significant activities. The regulatory and legal component of these activities consists in using effective legal rules of law to solve social problems and draft bills demand for which has been identified by situational analysis and discussions (when developing regulations, one must estimate social implications of their regulatory effect). Social projects are an integrated form of education where objects (simultaneously being subjects) of education (students, parents, teachers, executives) act jointly with a wide range of public and government entities.

Performance of the above forms of legal education relies, in many aspects, on reasonable organization of educational space (convenient premises with mobile furniture, advanced equipment and atmosphere contributing to communication); availability of educational materials to intensify education (collections of effective laws and regulations, videos, newspaper and magazine legal publications must dominate them). Legal education requires no new methods and forms of organizing activities, but demands new content of the existing ones.

The use of the above forms, approaches and methods of legal education must result into: - experience in using social (including legal) information including use of advanced communications means, critically processing legal information, making 


\section{CRIAR EDUCAÇÃO}

Revista do Programa de Pós-Graduação em Educação - UNESC

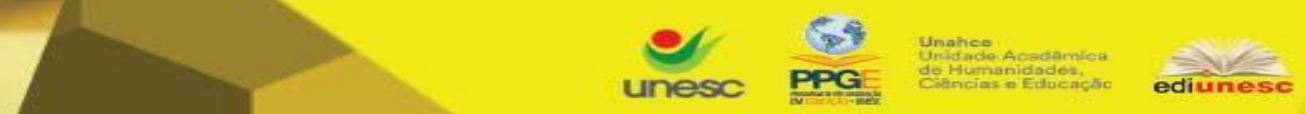

proprietary judgments and conclusions on the basis thereof, analyzing public phenomena and events, solving educational problems describing common legal situations, using the knowledge obtained to identify law-compliant conduct and procedures in specific situations; - skills in obtaining and systemizing legal information from different expressive systems (texts, schematics, tables), discerning facts and opinions, judgments and arguments in legal information, identifying correspondences of terms and definitions, concepts and their attributes, using legal knowledge, presenting proprietary judgments and arguments on specific social problems; - fostering positive life orientations based on democratic values of the modern society; - obtaining knowledge and skills of social functioning and abilities to adapt one's own behavior to the framework of existing liberties, rights and obligations.

Therefore, modern life makes legal education closely associated with moral and ethical education and contributes to young people's deeper understanding of moral and legal rules of conduct and instills in them responsibility for their actions.

\section{References.}

1. Buzunova, L.G. Guseva, L.G., Psychological diagnosis of the child's personality in preschool and elementary school. // Magnitogorsk: Magnitogorsk State University, 2009 $-76 \mathrm{p}$.

2. Guseva, L.G. Ethnopedagogy and intercultural communication in education. Magnitogorsk : NMSTU - 2015. - 43 p.

3. lakunina, E.A., Guseva, L.G. Kraevedcheskii muzei kak sredstvo dukhovnonravstvennogo vospitania mladshikh shkolnikov. Local Lore museum as a factor of moral education of elementary school children. / Aktualnye problemy sovremennogo obshego i professionalnogo obrazovaniia : Magnitogorsk, 2015. - 140 p. Pp. 122-125.

4. Martynova, N.V. Formation of personalisation in the youth environment /Young people in modern society / S.A. Burilkina, B.T. Ischanova, O.L. Potrikeeva, E.N. Raschikulina, G.A. Suprunenko : Magnitogorsk. 2015. pp. 177-181.

5. Martynova, N.V. Razvitie gotovnosti uchitelia k samo-imidgmaking $v$ sisteme vnutrishkol'nogo povysheniia kvalifikatsii. Candidate Ped. Sci. dissertation. Magnitogorsk. 2009. - 193 p. 


\section{Unesc PPGE de}

6. Martynova, N.V. Samopresentatsiia kak forma sotsial'noi raboty s molodezhiu. I Tekhnologii sotsial'noi raboty s molodezhiu / O.N.Vericheva, N.F.Basov. 2013. Pp. 403410.

\section{Martynova Natalia,}

Associate Professor, Institute of Humanitarian Education,

Nosov Magnitogorsk State Technical University,

Magnitogorsk, Chelyabinsk region, Russia

e-mail Martusnata@mail.ru

\section{Borovkova Nataliia,}

Associate Professor, Institute of Humanitarian Education,

Nosov Magnitogorsk State Technical University

Magnitogorsk, Chelyabinsk region, Russia 